\begin{tabular}{|c|c|}
\hline & $\begin{array}{c}\text { International Journal of Current Research } \\
\text { and Academic Review }\end{array}$ \\
\hline PUBLI & 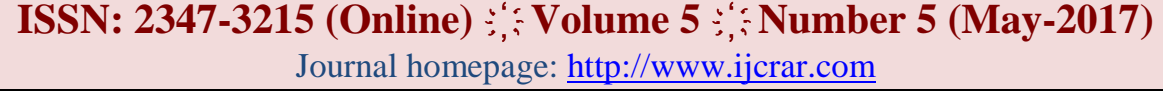 \\
\hline
\end{tabular}

doi: https://doi.org/10.20546/ijcrar.2017.505.014

\title{
Analysis of Mineral Nutrition of Different Seaweeds by using EDXRF Technique
}

\author{
D.Ch.Rajubabu ${ }^{1}$, A.Srinivasa Rao ${ }^{1}$, B.Aruna ${ }^{1}$, P.V.Lakshminarayana ${ }^{1}$, G.Mohan Narasimha Rao $^{2}$, \\ N.Satyanarayana ${ }^{3}$ and A.D.P.Rao ${ }^{1}$
}

${ }^{1}$ Department of Nuclear Physics, Andhra University, Visakhapatnam, India

${ }^{2}$ Department of Nuclear Physics, Andhra University, Visakhapatnam, India

${ }^{3}$ EDXRF Division, NCCCM. Hyderabad, India

*Corresponding author

\begin{abstract}
The aim of this study is to investigate the contents of essential, macro and micro elements by the energy-dispersive X-ray fluorescence spectrometry (EDXRF) in different seaweeds (10 red algae, 5 green algae)from collected different regions of Visakhapatnam coast(India). Seaweeds from different estuarine stations were analyzed by X-ray fluorescence, providing results for the concentration of total $\mathrm{K}, \mathrm{Ca}, \mathrm{Mo}, \mathrm{Mn}$, $\mathrm{Fe}, \mathrm{Co}, \mathrm{Ni}, \mathrm{Cu}, \mathrm{Zn}, \mathrm{I}, \mathrm{Na}, \mathrm{Mg}$, Se and $\mathrm{P}$. A radioisotope excited X-ray fluorescence analysis using the method of multiple standard additions was applied for the elemental analysis of seaweed samples. The results demonstrated that these seaweeds contain some essential element, but no toxic element. Edible green and red seaweeds could be used as a food supplement to help meet the recommended daily intake of some essential minerals and trace elements. Energy-dispersive X-ray fluorescence has been shown to be a suitable technique for multi-element analysis in this type of sample. No chemical pretreatment is required, minimizing sample contamination. The small amount of sample required, and the wide range of elements that can be detected simultaneously make energy-dispersive X-ray fluorescence a valuable tool for micro and macro elements analysis.
\end{abstract}

Article Info

\section{Introduction}

Biologically, seaweeds are classified as macroalgae, with subclassification as brown (Phaeophyta), red (Rhodophyta) or green algae (Chlorophyta).Currently, marine macroalgae or seaweeds are used worldwide for many different purposes. The human consumption of seaweed is common in Asian countries, mainly Japan, China, Korea, Vietnam, Indonesia and Taiwan (Dawes, 1988). Seaweed draws an extraordinary wealth of mineral elements from the sea that can account for up to $36 \%$ of its dry mass. The mineral macronutrients include sodium, calcium, magnesium, potassium, chlorine, sulfur and phosphorus; the micronutrients include iodine, iron, zinc, copper, selenium, molybdenum, fluoride, manganese, boron, nickel, copper and cobalt. Seaweed contains several vitamins. Red and brown algae are rich in carotenes (provitamin A) and are used, in fact, as a source of natural mixed carotenes for dietary supplements. The content ranges from 20-170 ppm. The vitamin $\mathrm{C}$ in red and brown algae is also notable, with contents ranging from 500-3000 ppm. Other vitamins are also present, including B 12, which is not found in most land plants. Seaweeds offer a wide range of therapeutic possibilities both internally and externally. The term Seaweeds in this case refers only to macrophytic marine algae, both wild and cultivated, growing in saltwater. Botanically, seaweeds are classified as Green, Brown, or Red. A particular seaweed's placement in one of these groups is determined first by its photosynthetic pigments, then its reproductive mode, then its micro and macro morphologies, and finally by its phycopolymers.

Dietary seaweeds provide all essential minerals. No land plant even remotely approaches seaweeds as sources of metabolically required minerals (See Bergner1997). 
Seaweeds can provide minerals often absent from freshwater and food crops grown on mineral-depleted soils. In addition to eating seaweeds regularly, those gardening for food can use copious amounts of seaweeds for much and fertilizer (Traditional Irish fertilizer, see: Man of Aran, and The Field), add seaweeds abundantly to compost, and even make seaweed tea sprayed directly onto leaves for foliar feeding through the stomata, as ways to therapeutically get trace elements into patients a trifle covertly. Seaweeds are $20-50 \%$ dry weight mineral (Kazutosi, 2002). This figure is obtained by burning off seaweed's organic material and weighing the remaining ash. The elements abundant in seaweeds include: potassium, sodium, calcium, magnesium, zinc, copper, chloride, sulfur, phosphorous, vanadium, cobalt, manganese, selenium, bromine, iodine, arsenic, iron, and fluorine.

Many human body substances require particular mineral elements as part(s) of their respective structure. Examples are iron for hemoglobin and iodine for thyroxine. For our bodies to function, we use proteins called enzymes. Most enzymes require one or more coenzymatic factors; these coenzymatic factors are usually one or more metal cations. Chronic dietary shortages or disease-related mineral depletions can produce both specific and general disease conditions: Iodine shortage results in varying degrees of thyroid dysfunction; poor absorption of dietary calcium can result in osteoporosis. Adequate residential body mineral supplies are critical for optimal body system functioning. My personal observations support the notion that nonspecific disease categories such as Chronic Fatigue, lack of energy, subclinical depression and depressed immunity are probably due to inadequate minerals either in the diet and /or in the body. Many times I have seen chronically exhausted patients exhibit complete symptom resolution after several weeks of adding 5-10 grams of seaweeds to their daily diets.

\section{Materials and Methods}

\section{Study area}

The study area of the sample collection was Visakhapatnam. Visakhapatnam lies on the east coast of India between latitudes $17^{0} 14^{1} 30^{\mathrm{ll}}$ and $17^{\circ} 45^{1}$ and longitudes $83^{0} 16^{1} 25^{11}$ and $83^{0} 21^{1} 30^{11}$ with vast resources of marine algal species.

\section{Collection of sample}

The seaweed samples were collect from the coast of Visakhapatnam. The algal sample was handpicked and washed thoroughly with seawater to remove all the impurities, sand particles and epiphytes, transported to the laboratory and washed thoroughly using tap water to remove the salt on the surface of the sample. The algal material was spread on blotting paper to remove excess water. They were shade dried. The dried seaweed is finally pulverized in the commercial grinder and powdered seaweed samples are used for further analysis

Procedures and apparatus Once at the laboratory, leaves and flowering samples were washed thoroughly with deionized water to remove superficial dust and ovendried at $55 \pm 5{ }^{\circ} \mathrm{C}$ for $24 \mathrm{~h}$. To reduce particle size they were ground in an agate ball mixer mill for 2-5 min. Once plant tissues were powdered and dried, they were kept in capped polypropylene flasks until analysis.

\section{Energy dispersive X-ray fluorescence (EDXF) method}

Three sub-samples of each powdered plant were pressed into pellets of $2.0 \mathrm{~cm}$ in diameter without any chemical treatment. Each pellet was glued on a Mylar film, on a sample E. Margu'1 et al. / Analyt. Experimental EDXRF set-up (triaxial geometry): (1) X-ray tube, (2) secondary target in molybdenum, (3) sample, (4) $\mathrm{Si}$ (Li) detector. Holder and placed directly on the X-ray beam for elemental determination. The spectrometer used in this work for the multi elemental measurements of vegetation specimens consists of an X-ray tube. With this arrangement it is possible to obtain a monochromatic source, which makes possible to select the secondary target in order to get the best excitation conditions for a specific sample. The X-ray tube, the secondary target and the sample are in a triaxial geometry (Fig. 1)

Samples were positioned according to the geometry (Tiraşoğlu et al., 2006). $1.85 \mathrm{GBq} 55 \mathrm{Fe}$ and 241Am radioactive sources excited by 5.96 and $59.54 \mathrm{keV}$ respectively, photon energies were used for direct excitation. The samples were analyzed in the form of pellets to obtain their characteristic X-ray spectra by using a collimated Ultra-LEGe detector having a thickness of $5 \mathrm{~mm}$ and an energy resolution of $150 \mathrm{eV}$ at $5.96 \mathrm{keV}$. The output from the preamplifier, with a pulse pile-up rejection capability, was fed to a multi-channel analyzer interfaced with a personal computer provided with suitable software for data acquisition and peak analysis. Spectra were analyzed using the Genie 2000 program and net peak areas were determined using the Origin 7.0 software program (Demo version). Each sample was irradiated for a time interval ranging from 2000 to 5000 s. A representative example of a spectrum is 
given in Figure 2 for elements excited by $55 \mathrm{Fe}$ and $241 \mathrm{Am}$ radioactive sources. In this study, the standard addition method was used to obtain the elemental concentration. The method involves the addition of known quantities of the analyte to the specimen. If analyte is presented at low levels and no suitable standards are available, standard addition may prove to be an alternative, especially if the analyst is interested in only one analyte element. The principle is as follows: Adding a known amount of analyte $\mathrm{i}(\Delta \mathrm{Wi})$ to the unknown sample gives an increased intensity $\mathrm{Ii}+\Delta \mathrm{Ii}$. Assuming a linear calibration, the following equations apply:

$\mathrm{Ii}=\mathrm{MiWi}$. For the original samples and $\mathrm{Ii}+\Delta \mathrm{Ii}=\mathrm{Mi}(\mathrm{Wi}$ $+\Delta \mathrm{Wi}$ ) for the sample with the addition.

Thus, the method assumes that linear calibration is adequate throughout the range of addition because it assumes that an increase in the concentration of analyte by amount $\Delta \mathrm{Wi}$ will increase the intensity by $\mathrm{Mi} \Delta \mathrm{Wi}$. These equations can be solved for the weight fraction of element $\mathrm{i}(\Delta \mathrm{Wi})$. To check the linearity of the calibration, the process can be repeated by adding different amounts of the analyte to the sample and plotting the intensity measured versus the concentration axis equals $\mathrm{Wi}$. The intensities used for calibration must be corrected for background and line overlap (Van Grieken, 1993).

\section{Results and Discussion}

\section{Elemental composition of algae}

Elemental composition determined by the EDXRF technique for the green algae (Ulva fascita, Enleromorpha Compressa, Spongomorpha Indica, Caulerpa Certeclariodes, Caulerpa Racemosa) and red algae (Gracillacia Cocticata, Jania Rubens, Gelidicem Peesileem, Amphiroa Fagillisma, Hypnea Valerctiae, Bryocladia Strunoids, Pteroclodia Heteroplotos, Gratelouphia Lithophila, Geliddiopsis Varialailis, Gelidiella Acerosa) are present in table.1 and table.2. The concentrations of 14 elements examined in 15 seaweed samples (10 red algae, 5 green algae) collected from Visakhapatnam region (RK beach and Tenneti park). The EDXRF method used in our study enabled a quantitative determination of a large number of elements. Major elements in the present different algae analyzed in this work are $\mathrm{Na}, \mathrm{P}, \mathrm{K}, \mathrm{Ca}, \mathrm{Mg}$ and minor elements are $\mathrm{Fe}, \mathrm{Co}, \mathrm{Cu}, \mathrm{Zn}, \mathrm{Mn}, \mathrm{Mo}, \mathrm{I}, \mathrm{Se}, \mathrm{P}$.

In nature, chlorine is found in the combined state only, chiefly with sodium as common salt $(\mathrm{NaCl})$. Potassium is never found free in nature and it is an essential constituent for plant growth and is found in most soils. Calcium is a metallic element, fifth in abundance in the earth's crust, of which it forms more than $3 \%$. Calcium is an essential constituent of leaves, bones, teeth, and shells. Calcium is never found in nature uncombined, but it occurs abundantly in limestone, gypsum, and fluorite. Iron is a vital constituent of plant and animal life and appears in hemoglobin. The pure iron metal is very reactive chemically and corrodes, rapidly, especially in moist air or at elevated temperatures. Iodine is a nonmetallic, solid element and it is only slightly soluble in water. Iodine is naturally present in the ocean, sea and some sea fish and water plants store it in their tissues. Iodine can be found naturally in air, water and soil. The most important sources of natural iodine are the oceans. Many medicines and cleansers for skin wounds contain iodine. Iodine is a building material of thyroid hormones that are essential for growth, the nervous system and the metabolism. If the iodine is excessively taken, it can be dangerous for human health because the thyroid gland labour too hastily. This affects the entire body; it causes disturbed heartbeats and loss of weight. Strontium reacts vigorously with water and quickly tarnishes in air. In this work, seaweed samples were collected in different years for a better investigation of mineral contents and heavy metal pollution. However; in this study the heavy metals having high toxicity were not found in the samples. Since the mineral content of $U$. lactuca varies according to the composition of sediment, sea water, sand, and rock, the absence of heavy metals in all samples suggested that most of the seaweed (U. lactuca) was collected from their nearly unpolluted natural habitats.

In present study investigation major elements such as $\mathrm{Na}$, $\mathrm{K}, \mathrm{Mg}$ elemental concentration increased in Spongomorpha indicaan decreased in Gracillacia cocticata than other algal samples. $\mathrm{P}$ elemental concentration increased in Gelidiella acerosa and $\mathrm{Ca}$ elemental concentration increased in Amphiroa fagillisma decreased in Gracillacia cocticata than other algal samples. Micro elements are like Fe elemental concentration increased in Caulerpa certeclariodes decreased in Ulva fascita than other algal samples. Co elemental concentration increased in Caulerpa certeclariodes decreased in Gracillacia cocticata than other algal samples, completely absent in Bryocladia strunoids and Geliddiopsis varialailis. $\mathrm{Cu}$ elemental concentration increased in Bryocladia strunoids decreased in Caulerpa racemosa than other algal samples. 
Table.1 Macro elemental concentration in different algal species in Visakhapatnam coast

\begin{tabular}{|l|l|c|c|c|c|c|}
\hline S.no & Sample name & $\mathrm{Na}$ & $\mathrm{P}$ & $\mathrm{K}$ & $\mathrm{Ca}$ & $\mathrm{Mg}$ \\
\hline 1. & Ulva fascita & 2.9868 & 229.514 & 337.2366 & 681.4152 & 2.9868 \\
\hline 2. & Enleromorpha compressa & 3.5786 & 269.440 & 140.7516 & 972.7499 & 3.5786 \\
\hline 3. & Gracillacia cocticata & 0 & 0.000 & 0 & 0 & 0 \\
\hline 4. & Jania rubens & 4.8749 & 152.555 & 42.8088 & 11409.98 & 4.8749 \\
\hline 5. & Spongomorpha indica & 5.7309 & 203.041 & 802.4727 & 4112.067 & 5.7309 \\
\hline 6. & Gelidicem peesileem & 5.4061 & 226.160 & 571.5148 & 823.1507 & 5.4061 \\
\hline 7. & Amphiroa fagillisma & 5.4476 & 204.932 & 160.3056 & 11720.38 & 5.4476 \\
\hline 8. & Hypnea valerctiae & 4.1431 & 268.760 & 139.9425 & 1191.071 & 4.1431 \\
\hline 9. & Caulerpa certeclariodes & 5.0301 & 160.394 & 67.6831 & 1017.274 & 5.0301 \\
\hline 10. & Caulerpa racemosa & 5.4389 & 202.270 & 111.023 & 1680.137 & 5.4389 \\
\hline 11. & Bryocladia strunoids & 4.5774 & 200.818 & 253.1675 & 1207.519 & 4.5774 \\
\hline 12. & Pteroclodia heteroplotos & 2.7865 & 231.178 & 88.9222 & 1662.309 & 2.7865 \\
\hline 13. & Gratelouphia lithophila & 3.6889 & 311.627 & 512.8387 & 1143.263 & 3.6889 \\
\hline 14. & Geliddiopsis varialailis & 3.7045 & 348.333 & 260.8334 & 1768.341 & 3.7045 \\
\hline 15. & Gelidiella acerosa & 3.9201 & 350.620 & 459.2309 & 1030.795 & 3.9201 \\
\hline
\end{tabular}

Table.2 Micro elemental concentration in different algal species in Visakhapatnam coast

\begin{tabular}{|l|l|c|c|c|c|c|c|c|c|}
\hline S.no & Sample name & $\mathrm{Fe}$ & $\mathrm{Co}$ & $\mathrm{Cu}$ & $\mathrm{Zn}$ & $\mathrm{Mo}$ & $\mathrm{Mn}$ & $\mathrm{I}$ & $\mathrm{Se}$ \\
\hline 1. & Ulva fascita & 286.3952 & 0.8971 & 17.9961 & 274.2428 & 1.3928 & 14.312 & 4.3363 & 0 \\
\hline 2. & Enleromorpha compressa & 5015.03 & 2.2305 & 33.6752 & 280.4997 & 0 & 60.1693 & 25.7759 & 0 \\
\hline 3. & Gracillacia cocticata & 329.9128 & 0.0201 & 7.355 & 125.4372 & 1.446 & 75.1748 & 8.305 & 0 \\
\hline 4. & Jania rubens & 1286.895 & 0.3542 & 5.8853 & 67.4193 & 0 & 44.8208 & 30.649 & 0 \\
\hline 5. & Spongomorpha indica & 5950.736 & 2.9047 & 33.5153 & 145.3244 & 0 & 246.454 & 215.5068 & 2.4298 \\
\hline 6. & Gelidicem peesileem & 1292.25 & 1.1083 & 51.5249 & 229.9564 & 1.5602 & 22.2432 & 303.0822 & 0 \\
\hline 7. & Amphiroa fagillisma & 720.8251 & 0.2731 & 4.8989 & 64.2264 & 0.4888 & 49.2956 & 43.399 & 0 \\
\hline 8. & Hypnea valerctiae & 1274.545 & 1.427 & 11.2837 & 291.5841 & 1.1347 & 39.2026 & 5.5322 & 0 \\
\hline 9. & Caulerpa certeclariodes & 6940.98 & 3.4672 & 41.8891 & 173.7804 & 0 & 76.2677 & 9.4832 & 3.8596 \\
\hline 10. & Caulerpa racemosa & 5640.284 & 2.829 & 39.748 & 944.1999 & 0 & 108.5158 & 9.1086 & 1.8055 \\
\hline 11. & Bryocladia strunoids & 6238.808 & 0 & 56.3849 & 519.1506 & 0 & 117.5049 & 36.7013 & 0 \\
\hline 12. & Pteroclodia heteroplotos & 3294.319 & 1.0233 & 23.4219 & 225.056 & 0.4889 & 57.6781 & 16.726 & 0 \\
\hline 13. & Gratelouphia lithophila & 680.8923 & 1.1237 & 21.1951 & 532.7459 & 1.6954 & 30.3461 & 170.4817 & 0 \\
\hline 14. & Geliddiopsis varialailis & 1735.392 & 0 & 15.5257 & 186.8577 & 0 & 35.8505 & 96.2967 & 0 \\
\hline 15 & Gelidiella acerosa & 739.6436 & 0.11 & 28.0674 & 590.4121 & 1.1283 & 38.0227 & 248.7544 & 0 \\
\hline
\end{tabular}

Zn elemental concentration increased in Jania rubens decreased in than other algal samples. Mo elemental concentration increased in Gratelouphia lithophila decreased in Amphiroa fagillisma than other algal samples, completely absent in Jania rubens, Spongomorpha indica, Caulerpa certeclariodes, Caulerpa racemosa, Bryocladia strunoids and Geliddiopsis varialailis. Mn elemental concentration increased in Bryocladia strunoids decreased in Ulva fascita than other algal samples. I elemental concentration increased in Gelidicem Peesileem decreased in Hypnea Valerctiae than other algal samples.. Se elemental concentration increased in Caulerpa certeclariodes complete absent in other algal species except Spongomorpha indica decreased in Caulerpa racemosa than other algal samples.

\section{Conclusion}

In this work, seaweed samples in different areas and different types for a better investigation and medicinal metal use. However; in this study the major and micro nutrients found in the samples. Since the mineral content of different samples varies according to the composition of sediment, seawater, sand and rock. In many countries, determination of micro and macro elements utilization of plant and human body by different species of marine algae have been carried out. the aim of this study investigation is micro and macro elements uses and functions in different criteria. This study will contribute to a better understanding of the mineral nutrition and importance of micro and macro elements. 


\section{References}

Aslan, A., Budak, G., Tıraşoğlu, E., Karabulut, A., Karagoz, Y., Apaydın, G., Ertuğral, B. and Çevik, U. 2004. Analysis of elements in some lichens by radioisotope X-ray fluorescence spectrometry. Frese. Environ. Bull., 13: 740-747.

Çevik, U., Ergen, E., Budak, G., Karabulut, A., Tiraşoğlu, E., Apaydin, G. And Kopya, A.I., 2003. Elemental analysis of Akçaabat tobacco and its ash by EDXRF spectrometry. J. Quant Spectrosc. RA, 78: 409-415

Dawes, C.J. 1988. Marine Botany, John Wiley and Sons, Inc., New York, U.S.A.

Margu'1, E., I. Queralt, M.L. Carvalho, M. Hidalgo. Comparison of EDXRF and ICP-OES after microwave digestion for element determination in plant specimens from an abandoned mining area Analytica Chimica Acta 549 (2005) 197-204.

Apaydin, G., V. Ayliker, E. Cengiz, M. Saydam, N. Kiip, E. Tirasoglu.2010. Analysis of metal contents of seaweed (ulva lactuca) from Istanbul, Turkey by EDXRF. Turkish journal of fisheries and aquatic sciences. 10: 215-220.

Mac Ardhur, J. D. and G. R. Palmer. 1983. Elemental analysis of algae with PIXE and PIGME. Nuclear Instruments and Methods in Physics Research 218; 519-524.

Lill, J.O., S.Salovius-Lauren, L.Rajander. K.-E Saarela, Aindroos, S.-J. Heselius.2012. Temporal changes in elemental compositionin decomposing filamentous algae (cladofora glomerata and pilayella littoralis) determined with PIXE and PIGE. Science of the total environment 414 ; 646-652.

Divya, K. and P. Kalyani. 2016. Influence of Seaweed Extract of Gracilaria Textorii and Turbenaria Arnata on the Germination, Growth and Yield of Some Vegetable Crops. Int. J. Pure App. Biosci. 4 (5): $42-$ 47.

Divya, K., N. Mary Roja and S.B. Padal.2015. Influence of seaweed liquid fertilizer of ulva lactuca on the seed germination, growth, productivity of Abelmoschus esculentus (L.). International Journal of Pharmacological Research ISSN: 2277-3312.

Kazutosi, Nisizawa.2002. Seaweeds Kaiso: Bountiful Harvest from the Seas. Sustenance for Health and Wellbeing

Tıraşoğlu, E., Çevik, U., Ertuğral, B., Apaydın, G., Baltaş, H. and Ertuğrul, M. 2005. Determination of trace elements in cole (Brassica oleraceae var. acephale) at Trabzon region in Turkey. J. Quant Spectrosc. RA, 94: 181-187.

Tıraşoğlu, E., Söğüt, Ö., Apaydın, G., Aylıkcı, V. and Damla, N. 2006. Elemental concentration analysis in some plant samples by EDXRF at Trabzon. J. Quant Spectrosc. RA, 102: 396-401.

Van Grieken, RE. and Markowiez, AA. 1993. Handbook of X-ray spectrometry, Marcel Dekker Inc., Bassel, Hong Kong, New York, 314 pp.

\section{How to cite this article:}

Rajubabu, D.Ch., A.Srinivasa Rao, B.Aruna, P.V.Lakshminarayana, G.Mohan Narasimha Rao, N.Satyanarayana and Rao, A.D.P. 2017. Analysis of Mineral Nutrition of Different Seaweeds by using EDXRF Technique.

Int.J.Curr.Res.Aca.Rev. 5(5), 101-105. doi: https://doi.org/10.20546/ijcrar.2017.505.014 